\title{
"I Do Not Own Gossip Girl": Examining the Relationship between Teens, Fan Fiction, and Gossip Girl
}

\author{
CAROLINE LAND \\ Edmonton Public Library
}

Fanfiction.net, an online fan fiction archive site, currently has over 5,800 titles about Gossip Girl, a series of books aimed at teens that has also been developed into a TV show. This article will look at what has been written on fan fiction and teens to date, introduce how Gossip Girl in particular lends itself to the creation of fan fiction, and discuss how teen writers are using Gossip Girl fan fiction and what they get out of writing. I will then conclude with a recommendation of some ways in which librarians, teachers, and others can incorporate fan fiction into their collections, spaces, lessons and programs in order to better serve the teens who create fan fiction.

\section{The Literature on Fan Fiction}

\section{Why Write Fan Fiction?}

The practice of fan fiction has existed for decades, but scholarly writing on the subject has only emerged over the last several years, and little has been written that focuses specifically on teens and fan fiction. Busse and Hellekson (2006) point out that "the history of fan fiction studies, for the most part, is a history of attempting to understand the underlying motivations of why (mostly) women write fan fiction" (p.17). Collins (2006), in one of the few articles that has researched the goals and motivations of fan fiction writers, concludes: readers seeking to [repeat the original experience of reading a particular

work of fiction] can perhaps find what they are looking for in fan fiction if aspiring fan fiction writers are capable of supplying answers to questions left by the original author in a manner that does justice to that author's style or writers can provide a unique but feasible insight into the original work. (p. 38)

Similarly, Thomas (2007) focuses on the experiences of two teen girls who were cowriting a piece of fan fiction. Thomas' article raises a number of considerations, such as the value for teens in writing fan fiction, the levels of access to technology needed to create fan fiction, and how teens use, create, and manipulate identity.

\section{Fan Fiction and Teens}

While Murray (1999) specifically explores "how one television program, My So-Called Life...activated the imaginations of a particular group of teen girls who, after viewing the show, met on-line in the winter of 1994-1995 to discuss and explore their subjectivity as female adolescents" (p. 222), she also suggests that "teen girls feel just as silenced by, and invisible to, television networks as they do by the culture at large" (p. 233). While the extent to which this statement is still true can be debated, it could help to explain the popularity of online avenues such as fan fiction and message boards among teens and teen girls in particular. Flench (1999) does now read as being dated, but her look at young fans and writers enables the reader to look 
back and see what has and has not happened in the decade since it was first published. From her experience in e-mailing young authors of fan fiction, she argues that "students should be informed that Web sites featuring fan-fiction exist and represent a valuable option for young people who crave an opportunity to be heard" (p. 46). She also provides a number of reasons why teachers and librarians should get involved with the promotion of fan fiction for the benefit of young writers. Also on a practical level, Segall (2008) is noteworthy in that the book has been specifically published with teens and young adults in mind. The book carefully and deliberately explores fan fiction and can be used as a resource for new writers.

\section{An Introduction to Gossip Girl}

Gossip Girl is a series of books that consists of twelve titles, including one prequel. The series also has two spin-off series, The It Girl and Gossip Girl: The Carlyles. The series is written by Cecily von Ziegesar, but according to Nussbaum (2005), several of the later titles have been written by a ghostwriter. The series follows a year in the lives of a group of high school seniors who live in and around Manhattan's Upper East Side. There are several central characters in the series, namely Serena, Blair, Nate, Jenny, Vanessa, and Dan. There are also a number of secondary characters that emerge largely as the lovers, rivals, or family members of the main characters.

Another central character is Gossip Girl, an unnamed person who runs a gossip blog detailing the secrets and actions of the citizens of the Upper East Side, especially the series' main characters. Gossip Girl usually gets the first and last words in any book through entries on the Gossip Girl blog, gossipgirl.net, which is also the website set up for the book series. A typical blog entry reads as follows:

\section{Sightings}

$\mathbf{D}$ and $\mathbf{V}$ with their lips locked down by the Seventy-ninth Street boat basin. It's kind of tragic how long it took them to realize they liked each other. $\mathbf{N}$ buying red roses for $\mathbf{J}$ - and you didn't think he had a sweet bone in his gorgeous stoner body. B and $\mathbf{S}$ heading into Bendel's to pick up their dresses for the Blackand-White ball tonight. (von Ziegesar, 2003, p. 1)

The voice of Gossip Girl sometimes also appears as an omniscient narrator who comments on the plot:

'I love you, too,' [Vanessa] whispered, closing [her eyes]. Briefly she considered asking [Dan] again if he wanted to try having sex but she didn't want to ruin the moment. She'd just have to wait until he was ready, although with Dan that might mean waiting until they were married or something.

Yawn. As if they didn’t act like they were already. (von Ziegesar, 2003, p.

Beginning in the fall of 2007, The CW Network began airing Gossip Girl as a television series. The program is an hour in length and while some plotlines from the book are followed, the television series has also created its own storylines and characters. The television program has won several Teen Choice Awards as well as being nominated for a 2008 People's Choice Award for Favourite New TV Drama. 


\section{Gossip Girl Fan Fiction}

Gossip Girl lends itself very well to the creation of fan fiction. It exists both as a book series and as a television series; an audience of both readers and viewers have been exposed to the characters and the plotlines. Additionally, there is a relatively high level of access to the source material. According to Nussbaum (2005), the books have sold millions of copies worldwide and can be found in many bookstores and libraries. The first season of the television show has been released on DVD, and episodes of the current season can be watched in the Unites States at www.cwtv.com and in Canada at www.ctv.ca. Also, Gossip Girl has a very high number of characters, including main characters, supporting characters, and incidental characters. Characters are not fully fleshed out in the series, which gives writers of fan fiction a chance to explore these characters on their own terms. Furthermore, the writing in Gossip Girl is quite repetitive. Characters are repeatedly described in the same way; Chuck Bass, for example is described in Gossip Girl as "handsome, after-shave commercial handsome" (von Ziegesar, 2002, p. 13), All I Want is Everything as being "handsome in a dark, after-shave commercial sort of way" (von Ziegesar, 2003, p.10) and in You Know You Love Me as "devastatingly handsome, in an after-shave commercial kind of way" (von Ziegesar, 2002, p. 202). While situations, such as romantic pairings, might change, the characters experience very little actual character development. As a result, the characters can easily be picked up and placed in original scenarios by new writers while still appearing to be in a story that is related to Gossip Girl.

There are many reasons why a teen may choose to write fan fiction, and Gossip Girl fan fiction in particular. The only way to actually know the exact reasons why would involve talking with each individual writer and asking them about their experiences with fan fiction. In looking at the existing Gossip Girl fan fiction, however, there does seem to be a number of common experiences among the writers.

In selecting pieces of fan fiction, there were two characteristics required: that they were written by teenagers and that they were about Gossip Girl. The following pieces of fan fiction were all found at www.fanfiction.net under the category of "Gossip Girl." All of the writers of these fan fiction stories have identified themselves as teenagers on their fanfiction.net profiles. The stories were located by looking at the profiles of authors who had published Gossip Girl stories. For the purposes of this article, I looked at both pieces of fan faction as well as the author's profile page. I examined the texts of both and observed the content of the story as well as what the author shared about his or her life. From these observations I identified repeated themes, patterns, and benefits of writing that could help to explain why teens would choose to engage in the creation of fan fiction.

\section{Creating Their Own World}

Gossip Girl fan fiction allows the writer to create a world in which the characters do exactly what they want them to do, as this disclaimer, taken from the fan fiction "Here \& Now" demonstrates: "I do not own Gossip girl or any of it's amazing characters. Note: Follows the events of season three final. Georgina's comeback or Chuck getting shot DID NOT happen," (xoxoDesireh, 2010). The writer here acknowledges that her version of Gossip Girl is different than the one shown on-screen. Fan fiction allows the writer the chance to have exactly what she wants: Georgina's comeback did not happen and Chuck did not get shot. There are many things in a teen's life that he or she does not have control over; creating a piece of fan fiction can be seen as exercising their own will over something they would otherwise not be able to control. 
One of the criticisms of the Gossip Girl series is its use of product placement, particularly as the series is aimed at a readership of teenage girls. A typical passage from a Gossip Girl novel reads as follows:

Mrs. van der Woodsen came in and sat down on the end of the bed. She was wearing a navy blue silk dressing gown by Oscar de la Renta and matching navy blue slippers. Her wavy blond-highlighted hair was pulled up in a loose bun on top of her head, and her pale skin had a pearly sheen from years of using La Mer skin cream. She smelled like Chanel No. 5. (von Ziegesar, 2002, You Know You Love Me p.32)

Specific attention is paid to how each character dresses, looks, even smells. There is a definite focus on the external qualities of characters; one way that status is conferred and wealth is determined is through the use of these product names.

Similarly, the fan fiction “The Greatest Day of Blair's Life or is it?” also includes a passage that makes use of brand names:

Blair Waldorf stared at herself in the dressing room at Barney's, making sure that the intentionally-destroyed True Religion jeans she was trying on were flattering enough for her to actually buy them. Yet, before she could check out how they made her butt look, her phone rang from the inside of her Louis Vuitton cherry bag. (Smearedeyeliner, 2005)

The references to Barney's, True Religion, and Louis Vuiton immediately mark this as a Gossip Girl story. This is not accidental, as this passage is also the first one in the story. Using the brands in this way can help the reader to ease into a new reality of Gossip Girl by introducing them through a world that they are quite familiar with. This is, though, the only passage in "The Greatest Day of Blair's Life or is it?" that features any kind of brand name; indeed, many of the fan fictions do not feature brand names or products. This suggests that for the writers of Gossip Girl fan fiction, the brands and status symbols of the series are a secondary, or even superfluous, aspect of the stories that are not necessary to include in fan fiction. This could potentially indicate that through leaving out or omitting the brand names, teens are able to take the world of Manhattan's Upper East Side and turn it into somewhere that looks a lot more like their own world.

\section{Making Connections with Fans and Writers}

One Gossip Girl fan fiction, "I Know You Want Me," begins with a note from the author: Heya! This is my first fic so I hope you like just the first chapter, I promise it gets better after this but I needed to get this out of the way first. I can't think of anything else to say right now except I don't own any of the characters and so on. Enjoy! (glitterglow, 2005).

The author, glitterglow, is using the introduction and disclaimer to connect with other fans on fanfiction.net. This friendly style extends to her profile where she reveals that her name is Fiona, she is nearly seventeen and that she lives near London, England, among other details about her appearance and personality (glitterglow, 2005). By sharing so much about herself, she moves away from just being a screen name and instead becomes more of an actual person. In establishing herself as an actual person with preferences and a personality, she is making it easier for other online people to connect to her as a writer. The author is learning how to exist as glitterglow and as Fiona at the same time; she is also learning how to manage an online profile 
that establishes herself online while also protecting some parts of her actual identity.

Similarly, ronXbouillabase, the 14-year old author of several Gossip Girl fan fictions, also has an extensive online profile. She lists her favourite books, movies, bands, television shows, and many other preferences, and concludes her profile with the following: "I am a hopeless romantic, a sincere Christian, an irritable babysitter (to my sister), and I love girl-hatesguy scenarios. And now that you know more than you ever wanted to know about me, let's see you NOT check out my stories beneath this paragraph!"' (ronXbouillabase, 2008). She has purposely written her profile in such a way as to entice the potential reader, to captivate their attention and attract them into reading her fan fictions. In addition to gaining skills related to writing and developing plot, she is also in a way learning how to market herself as a writer.

The writers of Gossip Girl fan fiction are not just getting a chance to connect with other fans of the series - they are getting a chance to connect with other writers. The fan fiction "Here $\&$ Now" includes comments that offer constructive feedback:

So I read chapter 1-7 all the way through and didn't have time to review. Sorry!

But now I can give you a proper review for this chapter to make up for it.

Firstly so far I'm in love with this story! It's really well written and although the story idea is a little cliche, the way you write it isnt. So that deserves some praise. Firstly, I think Jenny is going to want to keep the baby. I think Rufus was right when he talked to Lily last chapter. As much as Jenny isn't trying to attach herself to the baby she is. And Nate...he's a sweetie. I really think he'll be that support system (and father figure) to her baby. I'd really like to see that. And I love Dan/Serena so seeing them together makes me smile:) I also really like that Dan is being a friend for Blair. And Chuck...I don't know what to sayy. It's just a crapy situation all the way around. Please Update Soon:) (SingYourselftoSleep, 2010).

The reader, who goes by the name of Sing YourselftoSleep, is also a teenage girl who, according to her profile, also writes fan fiction for One Tree Hill and The Secret Life of the American Teenager as well as Gossip Girl. In this comment, the reader/fellow writer has offered a plot points to consider as well as encouragement for the developing story. Fan fiction, and the design of fanfiction.net, allows writers the chance to connect to other writers all over the world; the critique of their own work and the critiquing of others will help them to develop as writers.

\section{Instant Feedback}

One of the central features of fanfiction.net is that once a story has been published, or uploaded, readers can immediately begin to leave comments on the fiction. "Here \& Now" was updated on July 8, 2010, and on that same day the following comment appeared, directly relating to what had just been published:

So I hate allison. And I'm so glad that Lily is being there for Jenny in a way her mother can't be. good riddence lady, you're a complete bitch. And the DS reunion made me smile really big:) They're my ship and Ilovethem.

ahaha And I can't believe Vanessa would tell him via phone but at least people are starting to know. And the story is going to start moving along:) wooo-hooo.

Can't wait for more. Update Soon. (Sing YourselfToSleep, 2010). 
This short comment describes the reader's initial reaction to the chapter: references to specific parts of the chapter that she enjoyed, suggestions of what the reader would like to see in more chapters, and encouragement for the author to keep writing. The structure of fanfiction.net and fan fiction postings in general allows for the writer and the reaction of the audience to shape the action as the story develops, which allows the teen writers to feel as if they are part of a much larger community. Their identity as a fan fiction writer is being constructed as much through their writing as through their online profile, which can instil in the authors a sense of pride and accomplishment. And, given the instant nature of fan fiction feedback, all of this can take place in a relatively short period of time.

\section{The Role of Adults in Encouraging Writers of Fan Fiction}

Having looked at what teen writers practice and gain through their experiences of writing and publishing fan fiction, I believe that there is a place for teachers, librarians, and literacy educators in serving teens who are interested in or actively creating fan fiction. The following are a preliminary list of ways that adults can work to provide services for fan fiction-writing teens and young adults.

- Be informed about what fan fiction is and knowledgeable about the terms used by fan fiction writers

- Read or browse through online fan fiction sites (such as www.fanfiction.net) to see what popular topics are

- Be aware of and follow ongoing legal issues related to writing and publishing fan fiction

- Have general materials on writing in a school or library's teen collection, especially books that emphasize that writing for pleasure can be fun and enjoyable

- Have materials specifically on fan fiction in the library or classroom collection, such as fanzines about certain books or movies, or books aimed at teens like Career Building Through Fan Fiction Writing

- Provide materials for patrons on such topics as fan fiction in general or potential legal issues related to fan fiction

- Create book displays related to fan fiction, such as one promoting authors who started out as fan fiction writers (examples include Meg Cabot and Naomi Novik)

- Include fan fiction writers or writing at programming events related to popular books and/or movies (current examples include Harry Potter or Twilight which have over 460,000 and 153,000 pieces of fan fiction on fanfiction.net, respectively)

- Encourage reluctant writers to use fan fiction as a starting point for creative writing assignments

- Create space in a library's teen section for writing, including access to computers, power connections, internet connections and/or wireless internet, and chairs that are comfortable for sitting in for long periods of time

- Designate library computers and/or laptops that are specifically available to teens

\section{Conclusion}

The writing of fan fiction provides teens with a chance to learn a lot more than the characterization and plot development that goes along with writing. Fan fiction allows teens to take ownership of something that they enjoy, to connect with fans and writers all over the world, 
and to experience encouragement in something that they enjoy. While it is true that there are legal and ethical concerns over the writing of fan fiction, a quick look at fanfiction.net shows that this has not stopped many people, including teens, from writing and creating their own versions of established stories. Librarians and teachers need to be aware not only of what fan fiction is and how people use it, but also of what role there can be for them in serving the teen writers of fan fiction. Through serving this population, librarians and teachers can help to provide more teens with the resources to create their own works and to experience the world of writing firsthand.

\section{References}

Busse, K., \& Hellekson, K. (2006) Introduction: Work in Progress. In K. Busse \& K. Hellekson (Eds.) Fan Fiction and Fan Communities in the Age of the Internet (pp. 5-32). Jefferson, NC: McFarland \& Company.

Collins, T. (2006). Filling the gaps: What's happening in the world of fan fiction. Library Media Connection, (24)4, 36-38.

Flench, C.E. (1999) Young Adult Authors on the Internet. Book Report 17.4 (1999): 44-6.

glitterglow. (2005). I know you want me. Retrieved from http://www.fanfiction.net/s/2479771/1/I_Know_You_Want_Me

glitterglow. (2005). glitterglow. Retrieved from http://www.fanfiction.net/u/776073/glitterglow

Murray, S. (1999). Saving our so-called lives: Girl fandom, adolescent subjectivity, and My SoCalled Life. In M. Kinder (Ed.) Kids'Media Culture (pp. 221-235). Durham, NC: Duke University Press.

Nussbaum, E. (2005). Psst, Serena is a slut. Pass it on. New York Magazine. Retrieved from http://nymag.com/nymetro/arts/books/12058/

ronXbouillabase. (2008). ronXbouillabase. Retrieved from http://www.fanfiction.net/u/1693239/ronXbouillabase

Segall, M. (2008). Career building through fan fiction writing: New work based on favorite fiction. New York: Rosen.

Sing YourselftoSleep (2010, June 26). Reviews for Here \& Now [Msg 52]. Review posted to http://www.fanfiction.net/r/6038575/0/2/

Sing YourselftoSleep. (2010, July 8). Reviews for Here \& Now [Msg 75]. Review posted to Error! Hyperlink reference not valid.

Sing YourselftoSleep. (2010). SingYourselfToSleep. Retrieved from http://www.fanfiction.net/u/1793410/SingYourselfToSleep

Smearedeyeliner. (2005). The greatest day of Blair's life or is it? Retrieved from http://www.fanfiction.net/s/2399212/1/The_Greatest_Day_of_Blairs_Life_or_is_itr

Thomas, A. (2007). Blurring and Breaking through the Boundaries of Narrative, Literacy, and Identity in Adolescent Fan Fiction. In M. Knobel \& C. Lankshear (Eds.) A New Literacies Sampler (pp. 137-165). New York: Peter Lang.

von Ziegesar, C. (2003). All I want is everything: A Gossip Girl novel. New York: Little, Brown. von Ziegesar, C. (2002). Gossip Girl. New York: Little, Brown.

von Ziegesar, C. (2002). You know you love me: A Gossip Girl novel. New York: Little, Brown. xoxoDesireh (2010). Here \& now. Retrieved from http://www.fanfiction.net/s/6038575/1/Here_Now 


\section{AUTHOR BIOGRAPHY}

Caroline Land is a recent graduate of the School of Library and Information Studies at the University of Alberta. She is the Literacy Services Librarian at the Edmonton Public Library. Her interests include early literacy, children's literature, and materials for young adults. 